\title{
Chronic mast cell leukaemia with exon 9 KIT mutation A502_Y503dup: a rare imatinib responsive variant
}

\author{
Sukesh Manthri 이, ${ }^{1}$ Patrick N Costello, ${ }^{2}$ Koyamangalath Krishnan ${ }^{1}$
}

${ }^{1}$ Internal Medicine, Division of Medical Oncology, East Tennessee State University, Johnson City, Tennessee, USA ${ }^{2}$ Watauga Pathology, East Tennessee State University, Johnson City, Tennessee, USA

\section{Correspondence to} Dr Sukesh Manthri; sukeshmanthri123@gmail.com

Accepted 13 July 2020

\section{DESCRIPTION}

Mast cell leukaemia (MCL) is a very rare aggressive form of systemic mastocytosis (SM), representing $<1 \%$ of cases of adult SM in the USA. The diagnosis of MCL requires the presence of SM criteria accompanied by mast cells accounting for at least $20 \%$ of nucleated cells in bone marrow (BM) aspirate or $10 \%$ of peripheral blood white cells; cutaneous lesions are often absent. ${ }^{1}$ In patients with MCL, the absence of organ damage, the so-called 'C findings', serves as a diagnostic criterion of the chronic subvariant of MCL. ${ }^{2}$ Herein, we present a case of an aleukaemic chronic MCL with a rare KIT exon 9 mutation A502_Y503dup. A 60-year-old man developed recurrent episodes of flushing, headaches, dizziness and fluctuating blood pressure. Complete blood count showed a white blood cell count $13 \times 10^{9} / \mathrm{L}$, haemoglobin $123 \mathrm{~g} / \mathrm{L}$, haematocrit $35.7 \%$, mean corpuscular volume 98 fL and platelets $213 \times 10^{9} / \mathrm{L}$. A tryptase level was $71.9 \mu \mathrm{g} / \mathrm{L}$. Initial BM evaluation was consistent with SM with aberrant expression of CD2 and CD25. Allele-specific PCR for the KIT D816V mutation was negative. Repeat BM biopsy was obtained for KIT gene sequencing and showed an extensive mast cell infiltrate that was positive for CD2 (moderate, 27\%) and CD25 (weak, 29\%) and represented $60 \%-70 \%$ of marrow cellularity (figures 1-4). Next-generation sequencing revealed a KIT exon 9 mutation A502 Y503dup with an allele frequency of $3.4 \%$, as well was an ASXL1 variant (p.R402Q). Systemic imaging did not show any evidence of hepatosplenomegaly or lymphadenopathy. The absence of $\mathrm{C}$ findings, relatively low tryptase, low $\mathrm{Ki}-67(<5 \%)$ and the preponderance of immature mast cells without blastic morphology were

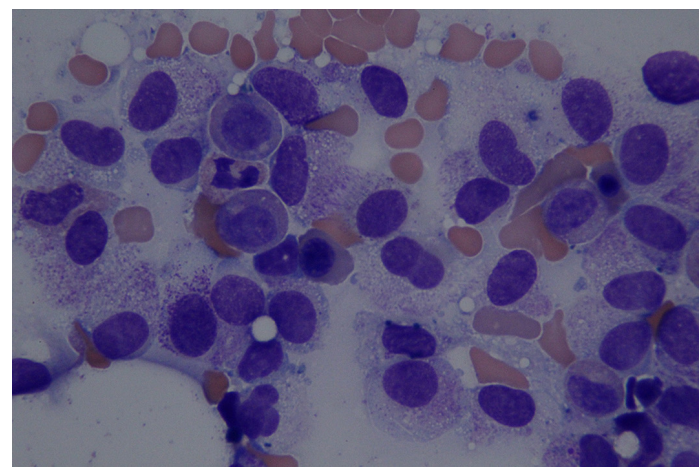

Figure 1 Wright-Giemsa stained bone marrow aspirate showing mast cells on $100 \times$ view.

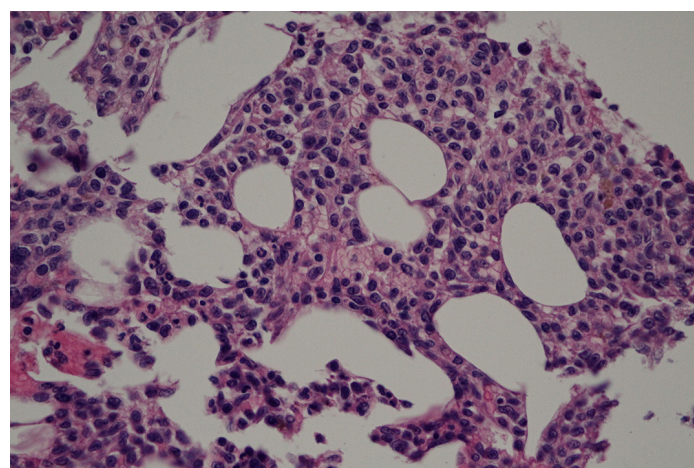

Figure 2 H\&E stained bone marrow trephine biopsy showing large mononuclear or spindle mast cells on $20 x$ view.

compatible with the non-WHO described chronic MCL variant of MCL. Cladribine or interferonalpha are no longer considered first-line treatments for cytoreduction due to modest overall response rates. Midostaurin is a multikinase/KIT inhibitor that is FDA-approved for the treatment of advanced $\mathrm{SM}$, including MCL. ${ }^{3}$ Imatinib is effective in a minority of SM patients only, as the most common

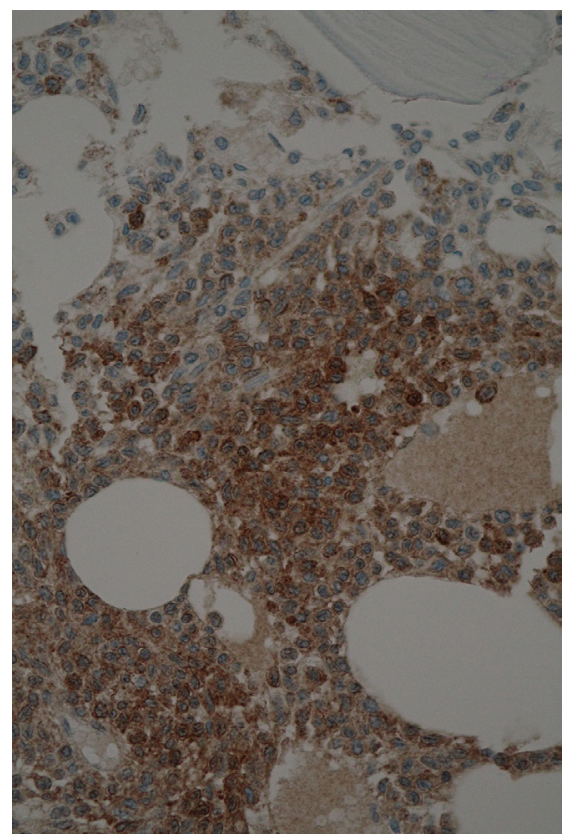

Figure 3 Immunohistochemistry of bone marrow core biopsy showing positive staining of tryptase containing mast cells on $40 \times$ view. 


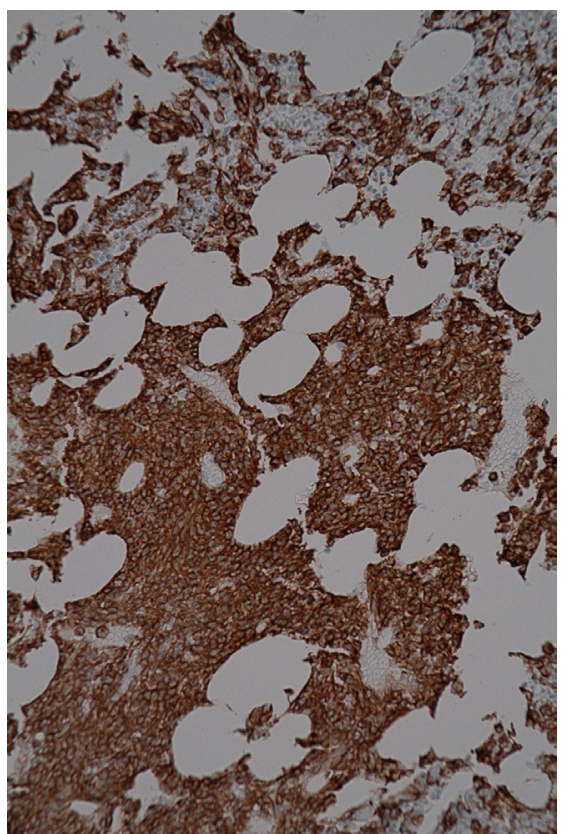

Figure 4 Immunohistochemistry of bone marrow core biopsy showing the CD117 positivity of mast cells on $20 \times$ view.

KIT mutation (D816V) is resistant to imatinib. ${ }^{4}$ In this case, given the presence of the rare variant exon $9 \mathrm{KIT}$ mutation, imatinib was recommended as initial therapy. The patient had persistent anaphylaxis that was refractory to standard supportive care, and omalizumab was recommended. The patient was recently started on imatinib $800 \mathrm{mg}$ daily. The anaphylactic episodes have resolved. MCL is a rare form of advanced SM, and in the absence of the typical KIT D816V mutation, a search for other mutations by sequencing the entire KIT gene should be considered, as this can influence the choice of treatment. The KIT exon 9 mutation A502_Y503dup was previously reported in patients with gastrointestinal stromal tumours. There has been no case of chronic MCL with this variant KIT mutation reported in the literature. Only one case of acute MCL with this variant KIT mutation has been reported previously in the literature, with a favourable response to imatinib. ${ }^{5}$

\section{Learning points}

- Mast cell leukaemia (MCL) is a rare and aggressive form of systemic mastocytosis (SM) characterised by leukaemic expansion of mostly immature mast cells, organ damage, drug-resistance and confers a poor prognosis.

- The diagnosis of MCL requires the presence of SM criteria accompanied by mast cells accounting for at least $20 \%$ of nucleated cells in bone marrow aspirate or $10 \%$ of peripheral blood white cells. The absence of organ damage, the so-called ' $C$ findings', serves as a diagnostic criterion of the chronic subvariant of MCL.

- Neoplastic mast cells display KIT D816V in only $50 \%-70 \%$ of the cases. In the remaining MCL cases, other KIT mutations or no KIT mutations are found. A search for other mutations by sequencing the entire $K I T$ gene should be considered, as this can influence the choice of treatment.

- Chronic MCL is an extremely rare but morphologically recognisable pathological variant of MCL.

Contributors SM worked on the abstract, and review of the literature. PNC provided pathological descriptions and images. KK supervised the process, reviewed and made final changes.

Funding The authors have not declared a specific grant for this research from any funding agency in the public, commercial or not-for-profit sectors.

Competing interests None declared.

Patient consent for publication Obtained.

Provenance and peer review Not commissioned; externally peer reviewed.

ORCID iD

Sukesh Manthri http://orcid.org/0000-0003-2390-3221

\section{REFERENCES}

1 Valent P, Sotlar K, Sperr WR, et al. Refined diagnostic criteria and classification of mast cell leukemia (MCL) and myelomastocytic leukemia (MML): a consensus proposal. Ann Oncol 2014;25:1691-700.

2 Valent P, Sotlar K, Sperr WR, et al. Chronic mast cell leukemia: a novel leukemia-variant with distinct morphological and clinical features. Leuk Res 2015;39:1-5.

3 Gotlib J, Kluin-Nelemans HC, George TI, et al. Efficacy and safety of midostaurin in advanced systemic mastocytosis. N Engl J Med 2016;374:2530-41.

4 Droogendijk HJ, Kluin-Nelemans HJC, van Doormaal JJ, et al. Imatinib mesylate in the treatment of systemic mastocytosis: a phase II trial. Cancer 2006;107:345-51.

5 Mital A, Piskorz A, Lewandowski K, et al. A case of mast cell leukaemia with exon 9 KIT mutation and good response to imatinib. Eur J Haematol 2011;86:531-5.

Copyright 2020 BMJ Publishing Group. All rights reserved. For permission to reuse any of this content visit

https://www.bmj.com/company/products-services/rights-and-licensing/permissions/

BMJ Case Report Fellows may re-use this article for personal use and teaching without any further permission.

Become a Fellow of BMJ Case Reports today and you can:

- Submit as many cases as you like

- Enjoy fast sympathetic peer review and rapid publication of accepted articles

- Access all the published articles

- Re-use any of the published material for personal use and teaching without further permission

Customer Service

If you have any further queries about your subscription, please contact our customer services team on +44 (0) 2071111105 or via email at support@bmj.com.

Visit casereports.bmj.com for more articles like this and to become a Fellow 